\title{
Parents' Involvement in Supporting Their Children Learn English
}

\author{
Isna Indriati \\ isna_iin@yahoo.com \\ MTsN 1 Model Palangka Raya \\ Jl. AIS Nasution No. 3 Palangka Raya, Kalimantan Tengah, Indonesia
}

Received: June 13, 2016; Accepted: August 22, 2016; Published: September 27, 2016

\begin{abstract}
This study focuses on the way of parents involving themselves in supporting their children learn English. In order to encourage children to learn better as English language learners, some parents send their children to have a continual program in non-formal institutions after schooling time. A common reason is that parents have the low capability in training their children to speak English or at least utter some meaningful words or phrases. Small scale survey by using open and closed-ended questionnaire was conducted among respondents from two elementary schools in Palangka Raya, Indonesia. They were, first, parents whose children learn English formally in SDIT Al-Furqan Palangka Raya and MIN Langkai Palangka Raya and take English course privately at home or courses center, and, second, the children as students. The questionnaires are focused on the students' attitude and motivation towards learning English and parents' opinions and involvement in learning the process, mainly practicing English at home. The result offers teachers some important points to consider in the teaching of English, especially the way to work with children and to build a positive relationship with parents in the regard of better learning.
\end{abstract}

Keywords: children, parents, English language learning

How to cite this paper: Indriati, I. (2016). Parents' Involvement in Supporting Their Children Learn English. Journal on English as a Foreign Language, 6(2), 145170. 
It is widely recognized that every child has uniqueness. Commonly, they like playing and interacting with others. Nearly all children cannot be forced to do something that they do not like unless we, teachers and parents as intruders, sink into their world. It is admired that children like singing, telling stories, playing kinds of games, talking and joking. It means that when they can express their feeling or desire easily, they can learn the language at ease. Dealing with English learning for children, there are two main factors that can help children maximize their learning; schooling and parenting.

School as an institution for formal learning provides a variety of listening and reading activities, language instruction, communication strategies, and consistent elaboration to help children acquiring oral and written language. These sorts of language exposure are frequently practiced in order that children achieve a minimum ability which is covered in the school curriculum. However, the result has not been well satisfied in improving students' capability instantly. This is caused by some factors. Firstly, the minimum time is allocated for English as the subject matter of most elementary schools in Indonesia. Secondly, most teachers who deliver English have less qualification whose basic education is elementary school one (Pendidikan Guru Sekolah Dasar). Besides, most parents have low ability in English or reluctantly use familiar utterances at home although they know English, even little. Moreover, children do not get the adequate experience of English practice since this language is not used as a means of daily communication by the society.

In relation to the problem above, teachers and parents should be actively involved in English language learning and development of their children. Parent involvement can be accomplished in a number of ways, including helping their children to problems dealing with their English homework if parents have an ability to do so, motivating them to follow English speech contest, or asking them to follow English courses. Through this way, parents who notably know little English can follow the progress of their children in learning English.

Assisting children in the process of learning and acquiring English as second or foreign language is not an easy task. It focuses on meaning rather than the form or pattern. Referring to Krashen's "Monitor Theory" (1981, p. 1), there are two systems of language development; subconscious language acquisition and conscious language learning. These systems are interrelated, but definitely, subconscious acquisition emerges to be more important. It is because practicing language will give more exposure to the learners rather than exploring grammar or form. That becomes the reason that promoting to practice English at home or environment is an essential factor in improving English. It 
seems that the children would be acquiring a new language while parents learning it.

The process of child development and maturation strongly influences language development. The problems teachers showed when giving instructions might be taken as an evidence of an overlook of the forces that drive children between 8 and 11 years old. Píaget cited by Suyanto (2010, p. 6) says that these children are at the concrete operational stage where experience plays a major role in all learning. When teachers work with children, their unique characteristics will appear naturally although some might raise problems. When teachers talk without engaging students' attention or students interrupt impatiently, it shows that children learn by doing (Holderness, p. 1991). If children are learning a language, they tend to talk all the time very often using their mother tongue. Children have a good instinct to get the sense or meaning of a situation. Demonstrations or modeling are valuable because they work out the meaning.

Thus, they interpret clues provided by the context or situation more quickly than words. The organization of pairs or groups is very important if teachers want to exploit children which are curious and active,_moreover when they are engaged in physical activities. This provides them a period of learning through interaction with other people (Brumfít, p. 1991). As well, Moon (2000, p. 53) states that children must be introduced to group work because they may not be familiar with this kind of working. Besides, checking understanding is also important, especially understanding of the whole message. In this case, teachers should always be aware and watch their faces, movements, and attitudes.

In line with the problems that commonly arise, Ur (1996) proposes some guidelines for giving effective explanations and instructions. Although she does not make a difference between directions for children or older students, her recommendations may well be applied to teaching children. She advises teachers to think ahead what words and illustrations to use. She also recommends making sure to have all the students' attention before giving instructions and or before dividing students into groups or handing out materials. The use of repetition or paraphrase, as well as the presentation of the instructions in different modes, is also proposed. She remarks the need to be brief in explanations when giving instructions to children which mainly contain a series of directives. Further, according to Sinclair and Coulthard cited by Holmes (1983) children will tend to respond to the final of a list of questions and commands. Besides, Ur (1996, p. 19) suggests that making an actual demonstration as part of the presentation of the activity either with the full class or with one student and also checking understanding (not just by asking 
students if they understand) by requesting them to do something that will show their understanding.

In summary, in order to avoid misunderstandings, it is necessary to provide rich contextual clues, including gestures, objects, and pictures. At the same time, teachers should try to avoid code-switching to the first language. This has an effect on students' talk because teacher talk is sometimes the only live target language that is available for their exposure. Nunan (1991) cites a study of target language use carried out by Zilm which revealed that an increase on the teacher's part in the use of the target language was followed by a parallel increase in the use of the foreign language by the students.

\section{METHOD}

This study applied descriptive quantitative. Based on Ary, Jacobs, and Sorensen (2010), quantitative research involves objective measurement and statistical analysis which can be presented in both table and words. The domains of research were parents' opinion, expectation, and involvement in English learning. Then, a small scale survey design was applied to collect data in which respondents are taken from two elementary schools. They are SDIT Al Furqan that has introduced English subject early at first grade and MIN Langkai that has presented English at third grade. In order to get target sample, the researcher collects names of students who join English courses. There were 200 respondents, consisting of parents and children. This research used probability random sampling design (Ross, n.d, p. 18) that was chosen under the consideration that these two elementary schools had been represented the students in one district. It was concluded that there was around 10 to 20 percent of students in each school who join extra English courses or a private one.

This study was conducted by delivering a package of the questionnaire (see Appendix) to the respondents; parents and their children who attend English private courses. There were seventeen questions for parents and eight ones for children. Three questions dealt with parents' background, including ages, profession, and knowledge of English. Next six questions were about children' ages, periods of learning English at both school and private courses, and the reason parents choose them. The following four questions asked for information on parents' opinion towards the need of learning English, improvement of their children capability in that language, their children interest in English and daily utterances that frequently used at home. The last four questions dealt with parents' expectation and involvement in assisting their children learns English at home. The eight questions distributed for children were used to dig information on their achievement at school, their opinions on learning English and speaking that language. Some questions 
explore the children partners in having a conversation or at least practicing some familiar utterances both at home and school.

\section{FINDINGS}

\section{Children Questionnaire}

The respondents of children who learn English at both school and private courses mostly sit on grade three, four, and five. They enjoyed learning English very much. Most of them had been participating in English lessons outside schooling for about 1 to 2 years. The main reason they join private courses was to improve their English knowledge. Those who said that they wanted to get good mark were children excluded of best ten of the class. The other reasons were to be able to speak English and pass the examination.

Dealing with the questions whether they like to speak English, almost all children said "yes". Nearly 60\% said that their English speaking partner was a mother. Based on the result of the question for children on some utterances that frequently used at home or school, they used at least 2 to 3 simple utterances to speak with parents, friends, or teachers. There were some utterances that most frequently used; Good Morning, Hello, Thank You, Ok/ Yes, No/Sorry, Bye/See You. Children whose parents had good knowledge in English were familiar with expressions for asking help or commands. The table 1 informed us about children age, interest, and reason.

Table 1. Information about Children

\begin{tabular}{ll}
\hline $\begin{array}{l}\text { Age of } \\
\text { Respondents }\end{array}$ & $\%$ \\
\hline $6-8$ & 26 \\
\hline $9-12$ & 74 \\
\hline
\end{tabular}

\begin{tabular}{ll}
\hline $\begin{array}{l}\text { Children Interest of } \\
\text { English Learning }\end{array}$ & $\%$ \\
\hline Very much & 76 \\
\hline Sometimes & 17 \\
\hline Less/No & 7.4 \\
\hline
\end{tabular}

\begin{tabular}{ll}
\hline Grade & $\%$ \\
\hline 1 & 7.4 \\
\hline 2 & 9.3 \\
\hline 3 & 23 \\
\hline 4 & 24 \\
\hline 5 & 28 \\
6 & 8.3
\end{tabular}

\begin{tabular}{ll}
$\begin{array}{l}\text { Duration of learning } \\
\text { English }\end{array}$ & $\%$ \\
\hline Less than 1 year & 44 \\
\hline 1 to 2 years & 46 \\
\hline More than 2 years & 9.3 \\
\hline
\end{tabular}




\begin{tabular}{ll}
\hline Children Reasons Taking English Course & $\%$ \\
\hline To get good mark & 25 \\
\hline To be able to speak English & 21 \\
\hline To improve knowledge of English & 44 \\
\hline To pass examination & 10 \\
\hline Because there are many friends to learn together & 0 \\
\hline
\end{tabular}

\section{Parents Questionnaire}

Information about parents' background described in Table 2 was obtained from the information given by parents; fathers or mothers as respondents. The various professions not only informed their way of living, but also their knowledge of English. Most of the parents said that they knew English although they did not master it. It showed that they had a good education, at least senior high school level. Parents' knowledge affected also on the reason they send their children to English courses, private or institutional. Moreover, all parents had a positive response that they were interested in participating themselves in their children English/foreign language acquisition process. Worthy respond was also given the question on whether learning English is important only whenever children get English at school, in which $98 \%$ respondents answered "NO".

Table 2. Parents' Background

\begin{tabular}{|c|c|c|c|}
\hline Parents Profession & Percentage & $\begin{array}{c}\text { Parents' knowledge of } \\
\text { English }\end{array}$ & $\%$ \\
\hline Civil Servant & 44 & \multirow{2}{*}{ Good } & \multirow{2}{*}{9} \\
\hline Officer & 4 & & \\
\hline Teacher/Lecturer & 6 & \multirow{2}{*}{ Adequate } & \multirow{2}{*}{80} \\
\hline Trader & 5 & & \\
\hline Other (worker, & 17 & \multirow{2}{*}{ Poor } & \multirow{2}{*}{11} \\
\hline Motherhood & 18 & & \\
\hline No information & 7 & & \\
\hline
\end{tabular}

Parents' reasons for encouraging their children to learn English in private /English course were various. For most respondents, helping their children understand English lesson at school is important. Eight parents added that English is necessary because as an international language people will need and use it to compete in the globalization era. Another stated that through learning English better and supported by good capability in a certain area, a child can go abroad to enroll a school there. Table 3 below shows the percentage of each option that was chosen by parents. 
Table 3. Parents' Reason for Sending Their Children Learn English in Private Courses

\begin{tabular}{lc}
\hline \multicolumn{1}{c}{ Reasons } & $\%$ \\
\hline helping children to understand English lesson at school & 64.81 \\
\hline helping children get a good mark & 26.85 \\
\hline $\begin{array}{l}\text { Introducing children that learning English will be easier at } \\
\text { young age }\end{array}$ & 58.33 \\
\hline Getting children like English & 40.74 \\
\hline Helping children to be able to communicate in English & 43.52 \\
\hline Equipping children with necessary skill in the future & 70.37 \\
\hline Opening children perspective on the importance of English & 37.96 \\
\hline Improving children English pronunciation & 40.74 \\
\hline
\end{tabular}

Dealing with the home language, a great number of respondents $(76 \%)$ used Indonesian to communicate. Some maintained using both Indonesian and mother tongue. Indirectly, parents kept their children know better about their genuine, home culture. This was proved by $12 \%$ parents who kept communicating by using their mother tongue only. Two respondents had interacted with their children in simple English although it was limited to instructions and responds of yes/no, sorry/ok, and greeting and thanking.

In supporting their children learning English better, parents also involved themselves with their children learning time. However, there were about $57 \%$ who actively accompanied their children practicing speaking English at home. The rest did not communicate in English to their child because they could not speak English. Some said that they did not have any confidence in speaking English because they were afraid of a mistake. Other two respondents argued that English was not community/social language, so they preferred using a language of society. Among the efforts that parents did, greeting and mentioning the name of things at home were the most frequent ways. Children whose parents had good knowledge in English got used to the activities like reading stories, simple English conversation, and instruction. From Table 4, we can see that most respondents did three common activities based on their ability. The first, third, and fourth options indicated that these three ways were practical for parents in a different level of knowledge since they are able to follow the materials being learned and their children are fond of their parents' companion. 
Table 4. Parents' Involvement in Practicing Speaking at Home

\begin{tabular}{ll}
\hline \multicolumn{1}{c}{ Way of Communicating } & $\%$ \\
\hline Speaking to children in English & 12 \\
\hline Reading English stories books & 12 \\
\hline Greeting children in English & 33 \\
\hline Mentioning some things at home in English & 34 \\
\hline Giving some instruction in English & 13 \\
\hline
\end{tabular}

Besides, dealing with parent's participation in their children English acquisition, some useful ways had been taken to help children learn English better. Among the efforts done by parents that are listed in Table 5, three preferred attempts to help children acquire language were by providing English source at homes such as books, cassettes, cards or pictures, helping children doing homework, and monitoring children English skills improvement. There were also two respondents who explained that they cooperated with children repeating and evaluating some of their child's English lessons at home, and singing English song through cassettes, and watching English film. However, in spite of their passive English speaking, 98\% of respondents were interested in participating child's language acquisition process. It means that English lesson given to younger children got a positive response.

Table 5. Parents' Participation in Children English Acquisition

\begin{tabular}{lc}
\hline \multicolumn{1}{c}{ Activities } & $\%$ \\
\hline $\begin{array}{l}\text { Giving her him some English learning source at home (books, } \\
\text { cassettes, cards, etc. }\end{array}$ & 54 \\
\hline $\begin{array}{l}\text { Communicating with her him in English, according to your } \\
\text { and/or your child's fluency's level }\end{array}$ & 14 \\
\hline Helping her/him with her his homework & 47 \\
\hline By following her/his English skills improvement & 45 \\
\hline $\begin{array}{l}\text { Proactively consulting to the teacher about your child's English } \\
\text { learning problems }\end{array}$ & 19 \\
\hline $\begin{array}{l}\text { Participating some activities (seasons' events, games, etc.) with } \\
\text { child in English class }\end{array}$ & 8 \\
\hline
\end{tabular}

Based on the answers the last question, parents' expectation from their children learning English was high. The three priorities chosen by parents were that children can understand English lesson at school, make children able to speak English and read/write in English. Detailed information is presented in Table 6. 
Table 6. Parents' Expectation from Learning English

\begin{tabular}{lc}
\hline \multicolumn{1}{c}{ Expectation } & $\%$ \\
\hline Help children understand English lesson at school & 77 \\
\hline Make children able to listen in English & 61 \\
\hline Make children able to read in English & 58 \\
\hline Make children able to speak in English & 68 \\
\hline Make children able to write in English & 58 \\
\hline Get children to know English songs, poems, games, and stories & 36 \\
\hline
\end{tabular}

The whole information above indicates that most of the respondents had good care about the English learning process for their children and that they seem to have a willingness to be involved. However, lack of knowledge and confidence in speaking brings parents to send their children to extra English courses to get more exposure and reach what they have expected.

\section{DISCUSSION}

\section{Children Characteristics as English Language Learner}

"Children would be acquiring language, while the parents would be learning it". The idea above is Stephen Krashen's. When we review that sentence, most people around us, especially children professionals, will agree a hundred percent. There are many reasons. First, a child tends to imitate whatever they see and hear from adults. Like learning a new language, a child will benefit his/her sense of hearing at the first time before he/she is able to read.

Children with their special characteristic of curiosity will indirectly take any kind of language input provided by their environment. If parents are not reluctantly using or at least mentioning some things at home in English, children will get new language exposure from their parents. This will be better if another family member can get involved. In this case, parents and older brothers and sisters who are good speakers of that language offer good reinforcement immediately. In short, through supporting language environment, a child gets many opportunities to speak the new language that is understood by others.

"Children are fond of playing". This is special characteristics of children that sometimes make adults, parents or teacher find difficulties to handle. Referring to Scott and Ytreberg cited by Suyanto (2010, p. 15), the ages of children, mostly go to level two that is at the age of 8 to 10 years. This group is often called as a beginner in which they start to learn English as a second language. On their ages, these children have been able to differentiate fact and fiction and begin to understand the abstract (non-concrete) thing. However, in order that they will not get bored easier, Ur (1996, p. 289) suggests three 
attractive ways draw children's attention so that they keep actively learning a new language. They are pictures, stories, and games. Through these interesting activities, adults, parents, or teachers could choose and implement one at their environment in such ways so that all get involved in learning and practice that new language.

"Children are intelligent to be able to cope with more than two languages". Nowadays condition which is related to people movement because of job or other reasons brings any effect to linguistics. In this case, parents and children need to interact with other people such as new neighbor that may have different daily language. If a child speaks Javanese at home and Indonesian at school and society, then move to another place in which most people speak Madurese, soon that child will adapt to the condition. At least, he/she will get used to hearing and understanding people speak Madurese but still unable to utter a simple sentence in that language for a period of time. Day by day, when she interacts with Madurese every day s/he will acquire a new language, that is Madurese. That is why children as newcomers will always be able to communicate with others because they are skillful, confident, and intelligent.

\section{Factors Determining Learning Success}

The ability comes more languages in certain situation becomes first of essential factors that determine a child' success in learning English as a new language. The event above may also happen in English learning. A child who lives in a setting that provides English exposure will easily improve their ZPD (Zone of Proximal Development) established by Vygotsky (Suyanto, 2010, p. 89) in which their social interaction helps their cognitive development. That is why mastering mother tongue or native and also second language should be supported by a parental companion who know better the need of their children. C. Snow cited by Ur $(1996$, p. 287) says that ages of 10 to 12 are the right period a child learn a new language other than hisher native because their logical thought has grown greater than the younger. This logical thinking helps them understanding what adults mean, want, or ask, although sometimes their understanding is still limited to their basic perception only. Meanwhile, Long cited by Ur (1996, p. 287) suggest that the earlier a child starts to learn a language, the better result will she get. However, her/his learning should be "maintained and reinforced" as the child grows older. This helps herhim to reach long-term learning purpose.

Accordingly, English for children of elementary school level has been established as local subject started from grade 4 to 6 , based on the Decree of Education Ministry No. 22/2006, in the date of May 23, 2006 (Suyanto, 2010, p. 4). In fact, many elementary schools have not had English teachers because they 
use the class teacher to hold some subjects at the same time. Those who have had English teachers introduced this lesson earlier in grade 1. Related to this fact, the result of this mini research shows that more respondents are from the school that introduces English at grade 3.

It implies that parents need to send their children to take English extra course as well as children want. When we see the reason parents send their children to take English courses after schooling, the main reason is that their children can keep up their English lesson at school after equipping children with necessary skill in the future. These reasons which are likely learning motivation become the second factor of language learning in which parents put their hope on children's success. When children get additional experience in private/institutional courses, they will not have a serious problem of understanding English lesson at school so they may get a good grade for that subject. This kind of extrinsic motivation is understandable (tolerable) because sometimes the schools ask too much from children. It is supported by Ur (1996, p. 287) that there is only one teacher among a number of children in the classroom so that exposure time is very limited and "survival" mode of learning cannot be fully applied.

In relation to children interest, it can be grounded from the children intrinsic motivation that they really like English and want to learn for the own sake or it may be because their parents arouse their children motivation to learn that language for better education and life. When children say that they take extra courses in order to get a good mark, they belong to motivated learners in which they maintain their 'ego involvement' and 'need for achievement' (Ur, 1996, p. 275).

In brief, whatever makes children like English; parents and community become the third main factor that helps children get their success. As children's primary teachers, parents are expected to have minimal English ability to support their children learning as well as the community. Ideally, people who work with children as English language learners should be able to speak both children's native and English. The community is the second partner of children to speak with after teachers at school and parents at home. If people of an environment use English for daily communication, children around there will get much exposure to English vocabulary and may be sentence structure.

However, it is very rarely a child get English exposure at home because of their enable parents to speak English, or because the society does not use that language for daily communication, like in our country Indonesia because it is a foreign language. Poorly stated, people tend to use their mother tongue or local language to speak with other from the same area or cultural background, which 
also happens in educational settings. Indonesian becomes the last choice if the listeners badly speak nothing.

Thus, parents who are unable to speak English or have little knowledge of English expect more from private course to give rich input to their children. Two ways communication between these parents and their children may limit on discussing the materials their children learn at school and at private courses. Here, perseverance becomes the fourth main factor in conditioning children to learn better. Ur (1996, p. 275) adds consistent efforts that children do without any discouragement from failure or lack of achievement will help children improve better. Jalal (2004, p. iv) suggests that parents, especially mothers who generally have a closer relation to any condition with children, should take perseverance as a magic key because it has a remarkable impact on anything that mothers do. As soon as mothers come and join with their children to start learning is better. Further, she adds that not all mothers have good English. They can learn at their children stage. The result, they can improve their English as well as their children. Her idea is in line with Krashen's that children acquire language while parents learn it.

Parents' background has also a significant effect on the children learning. A study on the relation between the quality and quantity of language input and its effects on children's vocabularies had been conducted by Hart and Risley cited by Cole (2008, p. 12-13). Their study found out that children from lowincome (low education) families generally "had vocabularies that were half the size" of those who were from high socio-economic status (high education background). From this result, they suggested that parents use a greater variety of word forms or tenses in present, past, and future, as well as declarations, and question forms. Shared book-reading experience between parents and children becomes another choice to encourage language input at home.

In short, a mutualism symbiotic will be well established at home through the process of learning. Based on discussion correlated with the findings, here are some approaches that can be formulated to encourage parents' involvement in the English learning process for their children. The following activities are taken from the options in the questionnaire given to parents as respondents. These, then are suggested to parents to follow the ways from the simplest to the most complex one.

1. Mentioning things at home in English; this can be started by giving a question such as"What is it?"

2. Helping them doing homework; through this activity, parents know the materials being learned by their children at school. If parents have adequate knowledge of English can follow the children skills improvement. However, the 
important thing that parents should have is perseverance. They consistent to learn together with their children.

3. Proactively consulting to the teacher about children English learning problems, this point will be discussed deeper in "parents and teachers engagement". Further, parents may ask for information to get their children participating in some English activities like contests in seasons' events, games, etc.

4. Greeting children in English is actually a starter of Speaking to children in English.

5. Giving some English learning source at home such as books, cassettes (songs and films), cards, and magazines, this, then, is followed by reading English stories books for them, sing or watch film together.

6. Starting to give some instruction in English in order that, day by day, parents can communicate with them in English, according to parents and/or children's fluency's level.

Thus, supportive parents have great influence on the children learning. Moreover, if parents do not allow their children speak their native or local language at school rather than at home, this will encourage them to speak Indonesian (in Indonesian context) at school and be more open to learning more. Likewise, when parents want their children to speak two languages, mother tongue and English as home language, a wide opportunity has been developed to improve children English acquisition. Therefore, it is possible to employ English as a home language other than native/mother tongue. Supporting the above opinion, Paradis, Kirova, and Dachyshyn $(2009$, p. 6) as principal writers of Alberta Education Cataloguing state that developing and maintaining a home language is so important. Through this way, parents or families can build children self-esteem that they have same values, belief, and other cultural understanding of their families.

The last but not the least is a teacher. This fifth factor is also very important since the nature and the quality of instruction for children as English young learners are highly demanded. It seems that some parents dissatisfied enough with teachers' effort in providing English exposure at school, that drive them to facilitate their children with an extra course in English. Here are some considerations that had been proposed by Coltrane (2003) in order that English teachers who engage closer to such condition can be children professionals. There are four important things deals with EYL teachers. First, ensuring teachers' quality means that EYL teachers are able to understand EYL linguistics needs, then prepare an effective lesson and provide instructions which appropriate to children characteristics and development. Second, providing sufficient opportunities for planning a high-quality program and instruction with a good framework of collaboration among other teachers and 
staff is needed to reach short and long term goals. Third, involving cognitive and social needs of young children into designed instruction is to cover children's developmental needs of learning at their own pace and in their learning styles. In this case, teachers are required to be creative and innovative to construct meaningful activities. Fourth, using funds of knowledge is in the regard of children and parents interest and enjoyment. Here, teachers may find out kinds of activities that frequently practiced at home, such as sing songs, or story reading/telling. A valuable task of teachers here is to create a positive home-school relationship.

Dealing with the home-school relationship, Paradis et al. (2009, p. 8-9) suggest some strategies that can be developed in engaging family and community into children meaningful learning. Here are three appropriate for the context of this research. Firstly, school or teachers may organize parents/community and school meetings and gathering. Through this activity, in one hand teachers can inform English learning program at a school in which children are engaged in. On the other hand, parents can share any problems that may be encountered at home. Parents may openly give suggestions or ideas towards English learning deals with children favors at home so that teachers/schools may integrate some themes related to children interests. Secondly, use informal notes and phone calls to share information or to express appreciation towards children achievement, or vice versa, towards teachers' dedication. Thirdly, school posts updated information on bulletin boards or school web. The information may contain school program in this context, English and special events on English activities. Here, the school may also display children's works as well as photographs in variety classroom activities.

To sum up, a large number of children who learn English in Indonesians schools are from families where English is not spoken. The five factors above are merely the simplest things that parents can be effortful together with teachers in order that children can learn as well as acquire English as a new foreign language. The very basic consideration that can make parents be proud of is that children have power learning inside of playing, curiosity for all new things, high capacity for memorization, and low level of anxiety. In such condition, parents will be at ease to get involved in learning together to maximize children achievement as what they have expected. Finally, a quotation from Easterbrooks and Baker cited by Cole (2008, p. 12) that "Successful children come from committed parents", may inspire us to have better improvement. 


\section{CONCLUSION}

Parents involvement were overall positive, means that their efforts are equal to what they expect from their children learning English both at school and at private courses. For them, it is important to equip children with necessary skill in the future, especially English. They are also very interested in facilitating children to acquire English as well as its essential knowledge to enable them to communicate and compete with others from the similar even different country. Other than that, reaching high achievement at school is a secondary reason.

For the writer, this research was a starting point to understand parents' involvement as well as their expectation of learning English for their children. She realizes that this survey is a brief and certainly not random in selection respondents. However, it has shown the significance of family perceptions in learning English and the support that they might give to their young children who are learning English for the first time, whether in preschool or elementary one.

It is then suggested to parents, as foremost partners of children in daily interaction, to encourage the quantity and quality of English utterances. For parents who have little/no knowledge of English can start to use English to interact by discussing the materials being learned at schools or courses. They may also accompany children doing homework, and mention name of things at home. Parents who able to speak in English can engage children to have a conversation based on children level. Those are the feature of supportive parents who have the great willingness for the better progress for both parents themselves and children.

An important contribution for teachers, especially EYL teachers, knowing children characteristics and needs is a trigger to develop suitable English lesson for children that center on various interesting and interactive activities, and involves physical movement but lead to developing their cognitive. Songs, stories in the form of picture series, puppets, or film, then games, and dances may accommodate children characteristics in which children have the power of imitating utterances, curiosity for new language items, high capacity for memorization and little fear of making mistakes. Additionally, routine and repetition could also be employed along with the opportunities to build interaction and cooperation among children, essentially their confidence. 


\section{REFERENCES}

Ary, D., Jacobs, L. C., \& Sorensen, C. (2010). Introduction to Research in Education (8th Ed.). New York: Wadsworth/Thomson Learning.

Brumfít, C . (1991). Teaching English to children. In C. Brumfit, J. Moon, \& R. Tongue (Eds.). London, U.K: Harper Collins Publishers.

Cole, M. (2008). The importance of parental involvement in language acquisition and activities and techniques to enhance the home-school connection. Paper 347 of Independent Studies and Capstones. Program in Audiology and Communication Sciences, Washington University School of Medicine. (Online).(http://digitalcommons.wustl.edu/pacs_capstones/347), assessed on January 25,2016 )

Coltraine, B. (2003). Working with young English language learners: some consideration. Eric Digest, May 2003. (Online). Assessed from http://www.cal.org/resources/digest/digest_pdfs/0301coltrane.pdf on March 2, 2012.

Holderness, J. (1991). Activity-based teaching: Approaches to topic-centered work. In C. Brumfit, J. Moon, \& R. Tongue (Eds.). Teaching English to Children London, U.K.: Harper Collins Publishers.

Holmes, J. (1983). The structure of teachers' directives. In Richards, J. and Schmidt, R. (Eds.). Language and Communication. England: Longman.

Jalal. (2004). Mother talk: before five years old. Jakarta: PuspaSwara.

Krashen, S. D. (1981). Second language acquisition and second language learning. California: Pergamon Press.

Moon, J. (2000). Children learning English. Oxford: Macmillan Heinemann.

Nunan, D. (1991). Language teaching methodology. Great Britain: Prentice Hall.

Paradis, J., Kirova, A., \& Dachyshyn, D. M. (2009). Working with young children who are learning English as a new language. In Alberta Education Cataloguing. Alberta: The Crown. (Online). Assessed from http://education.alberta.ca/media/1093791/earlylearning.pdf, on January 4, 2016.

Ross, K. N. (n.d). Sample design for educational survey research. UNESCO. (Online). (http://www.sacmeq.org/downloads/modules/module3.pdf), accessed on October 26, 2015.

Suyanto, K. S. E. (2010). English for young learners: melejitkan potensi anak melalui English class yang fun, asyik, dan menarik. Jakarta: Bumi Aksara.

Ur, P. (1996). A course in language teaching: Practice and theory. Cambridge: Cambridge University Press. 


\section{Author's Brief CV}

Isna Indriati is an English teacher of MTsN 1 Model Palangka Raya. She earned her undergraduate degree at UNESA and post-graduate one at UM. She has actively joined conferences within various themes both as presenter and participant in improving her knowledge and capability in English. 


\section{Appendix: Questionnaire}

\section{(Indonesian Version)}

\section{QUESTIONNAIRE}

Assalamu'alaikum wr.wb.

Bapak/lbu responden yang terhormat,

Orang tua adalah motivator belajar terbaik bagi anak, disamping guru-guru di sekolah. Demikian halnya dalam pembelajaran Bahasa Inggris, sebagai bahasa asing.Kuisioner ini saya sampaikan untuk mendapatkan informasi tentang dukungan dan peran serta orang tua dalam meningkatkan kegiatan pembelajaran BahasaInggris.InformasidariBapak/hbumenjadi data pokok dalam penyusunan makalahberjudul "Keterlibatan Orang TuaDalam Proses Pembelajaran Bahasa Asing (Inggris) Anak". Data dari kuisioner inimenjadi data pribadi saya yang tidak akan digunakan oleh pihak lain. Semoga hasil penelitian ini dapat memberikan kontribusi ide terhadap guru-guru Bahasa Inggris di sekolah serta orang tua, khususnya penulis.

Dalam amplop inisaya berikan dua (2) macam angket, satu untuk orang tua, dan satu untuk anak.Mohon bimbingan Bapak/bu untuk mengisi angket tersebut, serta mengingatkan putra/putri bapak/lbu untuk membawa kembali ke sekolah.Demikian, atas kerjasama Bapak/lbu saya ucapkan terimakasih.

Wassalamu'alaikum wr.wb.

Isna Indriati

\section{KUISIONER UNTUK ORANG TUA}

1. Berapa usia Anda?

2. Apakah pekerjaan Anda?

3. Apakah Anda mengenal dan menguasai Bahasa Inggris?
a. ya, sangat baik
b. ya, tapi kurang menguasai
c. tidak

4. Berapa usia putra/putri Anda?

5. Berapa lama (jam pelajaran/pertemuan) putra/putri Anda belajar Bahasa Inggris di sekolah?

6. Di manakah putra/putri Anda mengikuti les Bahasa Inggris?

7. Sejak kapan putra/putri Anda belajar Bahasa Inggris di lembaga kursus (privat)? 
8. Apa alasan Anda memilih lembaga kursus (privat) tersebut?

9. Berapa kali (pertemuan) per minggu putra/putri Anda belajar Bahasa Inggris di tempat les (privat)?

10. Apakah Anda ingin dan tertarik untuk membantu putra/putri Anda dalam meningkatkan kemampuan berbahasa Inggris?
a. ya
b. tidak
c. tidak tahu

11. Apakah menurut Anda pembelajaran Bahasa Inggris hanya perlu saat anak mendapat materi Bahasa Inggris di sekolah?
a. ya
b. tidak
c. tidak tahu

12. Apa putra/putri Anda menyukai pelajaran Bahasa Inggris?
a. sangat suka
b. kadang-kadang
c. kurang
d. tidak tahu

13. Bahasa apa yang Anda gunakan sehari-hari? (beri centang, boleh pilih lebih dari satu)
a. bahasa ibu (.... ...)
b. Bahasa Indonesia
c. Lainnya:

14. Apa alasan Anda menginginkan putra/putri Anda belajar Bahasa Inggris? (beri tanda centang $\sqrt{ }$ pada pilihan yang sesuai alasan Anda, boleh pilih lebih dari satu)
a. untuk membantu anak lebih memahami materi belajar di sekolah
b. agar mendapatkan nilai yang bagus/memuaskan
c. karena belajar Bahasa Inggris itu mudah saat anak masih usia dini $\square$
d. untuk membuat anak menyukai Bahasa Inggris
e. agar anak dapat berkomunikasi (bicara) dalam Bahasa Inggris
f. membekali anak dengan ketrampilan penting untuk masa depan
g. untuk membuka pemikiran anak tentang pentingnya Bahasa Inggris $\square$
h. untuk mengembangkan kemampuan pelafalan Bahasa Inggris anak
i. Alasan lain :

15. Apakah Anda sering bicara dalam Bahasa Inggris dengan putra/putri Anda?

a. ya

bila 'ya', bagaimana Anda berkomunikasi? (boleh pilih lebih dari satu)

a. berbicara dengan anak dalam Bahasa Inggris

Journal on English as a Foreign Language, 6(2), 145-170

Copyright @ 2016 by JEFL, p-ISSN 2088-1657; e-ISSN 2502-6615 
b. dengan membacakan cerita berbahasa Inggris

c. dengan memberi salam atau sapaan dalam Bahasa Inggris

d. dengan menyebutkan nama benda-benda di rumah dalam Bahasa Inggri

e. dengan member instruksi/perintah dalam Bahasa Inggris

f. lainnya:

b. tidak (Anda bebas memberikan alasan:

16. Bagaimana Anda terlibat dalam usaha peningkatan kemampuan berbahasa Inggris putra/putri Anda? (boleh pilih lebih dari satu)

a. menyediakan sumber belajar Bahasa Inggris di rumah (buku, kartu, kaset)

b. berbicara dengan anak dalam bahasa Inggris berdasarkan materi yang dipelajari di sekolah atau di tempat les

c. membantu anak mengerjakan pekerjaan rumah (PR)

d. mengikuti perkembangan belajar anak

e. secara aktif berkonsultasi dengan guru di sekolah atau di les tentang perkembangan belajar anak atau permasalahan belajar

f. meng ikutsertakan anak dalam bermacam kegiatan bahasa Inggris, misalnya lomba atau permainan

g. lainnya :

17. Apa yang Anda harapkan dari pembelajaran Bahasa Inggris putra/putri Anda? (boleh pilih lebih dari satu)

a. anak memahami pelajaran Bahasa Inggris di sekolah

b. anak mampu mendengar (menyimak) dalam Bahasa Inggris

c. anak mampu membaca dalam Bahasa Inggris

d. anak mampu berbicara dalam Bahasa Inggris

e. anak mampu menulis dalan Bahasa Inggris

f. anak tahu bermacam lagu, syair, permainan, dan cerita dalam Bahasa Inggris

g. lainnya:

** Terimakasih ** 


\section{KUISIONER UNTUK SISWA}

Lingkari jawaban yang kamu pilih.

1. Apakah kamu masuk rangking 10 besar?
a. ya, rangking ....
b. tidak, rangking ....

2. Bagaimana belajar Bahasa Inggris itu?
a. sangat menyenangkan
b. menyenangkan
c. membosankan

3. Mengapa kamu les Bahasa Inggris?
a. agar mendapat nilai bagus di sekolah
b. agar dapat bicara dalam Bahasa Inggris
d. agar pengetahuanku tentang Bahasa Inggris bertambah
e. agar lulus ujian dengan nilai memuaskan
f. karena banyak teman untuk belajar

4. Apa kamu senang berbicara Bahasa Inggris?
c. iya
d. tidak

5. Manakah ungkapan yang sering kamu ucapkan di rumah dengan orang tuamu? (bisa pilih lebih dari satu)
a. Good Morning
m. Come in/Come here
b. Hello
n. Let me see
c. Excuse me
o. Look
d. Yes/Ok
p. Hurry up
e. Sorry No
q. How much?/How many?
f. How are you?
r. Don't forget
g. Please/May I?
s. Let's go
h. Thank you
t. See you
i. Can you help me?
u. Goodbye/Bye
j. Very good/Good
v. Take care be careful
k. Now/Tomorrow
w. Wait a minute
1. What's up?
x. Tell me
y. Lainnya:

6. Siapa yang sering mengajak kamu berbicara bahasa Inggris di rumah?
a. Ayah
b. Ibu
c. Saudara Kakak

7. Apakah kamu pernah berbicara Bahasa Inggris dengan temanmu?

8. Manakah ungkapan yang sering kamu ucapkan dengan temanmu di sekolah? 
(bisa pilih lebih dari satu)
a. Good Morning
b. Hello/Hi
c. How are you?
d. What's up?
e. Bye
f. See you
g. Thank you
h. Please May I
i. Yes
j. No/Sorry

** Terimakasih ** 


\section{Isna Indriati}

\section{(English version)}

Dear participants,

Parents are the best motivator for children to learn at schools with teachers, as well as in learning English as a foreign language. This questionnaire is for obtaining valuable information regarding parents' involvement and support to encourage children's English learning. The information gathered from the questionnaire will be the main data for writing an essay paper entitled "Parents' Involvement in Supporting their Children Learn English". The information you provide will only be used for my paper and will be not be used by any another person. Hopefully, the result of this research will give beneficial contribution for English teachers at schools and parents, especially the writer.

In this envelope, there are two questionnaires, one for a parent, and another one for a child. I need your guidance to help your child answer the questions and remind him/her to bring it back to school.

Thank you for your time and cooperation.

\section{QUESTIONNAIRE FOR PARENTS}

1. How old are you?

2. What is your profession?

3. Do you know English better?

a. yes, very good

b. yes, but not good enough

C. no

4. How old is your child?

5. Does your child learn English at school? Yes $\quad \square \quad$ No How long?

6. Where does your child attend an extra English course?

7. When does your child start to learn English at an English course or private one?

8. Why do you choose that English course (private)?

9. How often does your child learn at English course (private) in a week?

10. Are you interested in helping your child improve their English skills?
a. yes
b. no
c. undecided

Journal on English as a Foreign Language, 6(2), 145-170

Copyright (C) 2016 by JEFL, p-ISSN 2088-1657; e-ISSN 2502-6615 
11. Do you think that English learning is only needed when a child get English lesson at school?
a. yes
b. no
c. undecided

12. Does your child like English?
a. Very much
b. Sometimes
c. Less
d. No

13. What is your daily language? (You can give tick more than one answer)
a. Mother tongue $(\ldots \ldots \ldots \ldots \ldots \ldots \ldots \ldots)$
b. Indonesian
c. Others:

14. Why do you want your child to learn English? (You may choose more than one answer)
a. to help her him understand English lesson at school
b. to get good mark/grades
c. because it is easier to learn a language at a young age
d. to get children like and enjoy English
e. to make a child be able to communicate in English
f. to equip her him with necessary skills for the future
g. to open children's insight the English importance
h. to improve children's English pronunciation
i. other:

15. Do you often/sometimes communicate in English to your child?

e. Yes.

If "Yes", how do you communicate in English with her/him?
a. by speaking to children in English
b. by reading English stories books to children
c. by greeting children in English
d. by mentioning some things at home in English
e. by giving some instructions in English
f. other:

f. No. (please write down the reason

16. How do you participate in their child's language acquisition?(you may choose more than one answer)
a. by giving children some English learning source at home (books, cassettes, cards, etc)
b. by discussing with children about their English material at school or course
c. by helping children doing their homework, if necessary
d. by following childrenEnglish skills improvement 
e. by proactively consulting to the teacher about your child's English learning problems

f. by involving children in English activities (seasons' events, games, etc)

g. other:

17. What do you expect from your child's English lessons?(please choose three priorities)

a. help children understand English lesson at school

b. make children able to listen in English

c. make children able to read in English

d. make children able to speak in English

e. make children able to write in English

f. make children know some English songs, rhymes, games, children stories.

g. other:

$$
\text { ** Thank You ** }
$$

\section{QUESTIONNAIRE FOR CHILDREN}

\section{Circle your choice.}

1. Do you go to the best ten?
a. yes
b. no

2. What do you think of learning English?

g. Very exciting

h. Exciting

i. Boring

3. Why do you take a English course?

c. To get good mark at school

d. To be able to speak English

e. To improve knowledge of English

j. To pass examination with good grade

k. Because there are many friends to learn together

4. Do you like to speak English?
a. yes
b. no

5. Which utterances do you frequently use to speak with your parents? (you may choose more than one)
a. Good Morning
m. Come in $/$ Come here
b. Hello
n. Let me see
c. Excuse me
o. Look 
Isna Indriati
d. Yes/Ok
p. Hurry up
e. Sorry $\mathrm{No}$
q. How much?/How many?
f. How are you?
r. Don't forget
g. Please May I?
s. Let's go
h. Thank you
t. See you
i. Can you help me?
u. Goodbye/Bye
j. Very good/Good
v. Take care be careful
k. Now/Tomorrow
w. Wait a minute
1. What's up?
x. Tell me
y. Other:

6. Who usually invite you to speak English at home?

d. Father

e. Mother

f. Brother/Sister/Siblings

7. Do you speak with your friends in English?

8. Which utterances do you frequently use to speak with your friends? (you may choose more than one)
k. Good Morning
1. Hello/Hi
m. How are you?
n. What's up?
o. Bye
p. See you
q. Thank you
r. Please May I
s. Yes
t. No/Sorry

** Thank You ** 